International Journal of Pediatric Research and Reviews

(ISSN:2637-4978)

\title{
EVALUATION OF MEDIMENTAL INTOXICATIONS IN CHILDREN
}

\section{Ortência Kelly Jacinto Rodrigues $^{1}$ *, Adna Maria Tavares ${ }^{1}$, Waleska Ramos Souza ${ }^{1}$, Cinthya Maria Pereira de Souza ${ }^{2}$}

${ }^{1}$ Discente do curso de Farmácia UNIFACISA; ${ }^{2}$ Docente do curso de Farmácia UNIFACISA.

\begin{abstract}
Introduction: Drug poisonings arise due to complex mechanisms and the high rate of these events in our country is multifactorial, among them a wide variety of formulations, the pro-

*Correspondence to Author: liferation of drugstores, prescription errors and pharmaceutical Ortência Kelly Jacinto Rodrigues Discente do curso de Farmácia dispensing, allied to a weakness in the ability to supervise. Objective: To evaluate the occurrence of drug poisoning in children, identifying the main classes and factors involved. Methodology: How to cite this article:

This was a descriptive study, such as literature review. The fol- Ortência Kelly Jacinto Rodrigues*, lowing search descriptors "intoxication", "medicines" and "chil- Adna Maria Tavares, Waleska Radren" were searched, integrated in the SCIELO and MEDLINE mos Souza, Cinthya Maria Pereidatabases. Results: Cases of drug poisoning in children aged 0 ra de Souza. EVALUATION OF to 9 years represent $33 \%$ of the total cases. Although the main MEDIMENTAL INTOXICATIONS IN cause is attempted suicide in the child population, the highest CHILDREN. International Journal incidence was due to accidents, or after a medical prescription, of Pediatric Research and Reviews, with errors in administration. The main drugs involved were na- 2020, 3:23

sal decongestants, bronchodilators, analgesics and anti-inflammatories. Conclusion: The occurrence of drug intoxications is frequently recorded in health systems, and the percentages are higher in children, so it is of utmost importance that the teaching about the use of medicines is carried out from the earliest years of life.

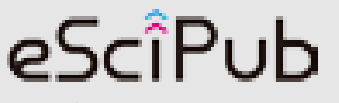

eSciPub LLC, Houston, TX USA. Website: https://escipub.com/

Keywords: Intoxication, Medicines, Child.
\end{abstract}




\section{INTRODUCTION}

Medicines constitute the pharmaceutical product, technically obtained or elaborated, for prophylactic, curative, palliative or diagnostic purposes, being responsible for a significant part of the increase of the population's expectation and quality of life. However, they have the ability to cause damage to the patient's health and may result in death. 1 Drug poisonings arise due to complex mechanisms, which may be related to individual characteristics, pharmacodynamic and pharmacokinetic processes, which may vary in relation to the pharmaceutical properties of the product and presentation, and are also involved with interactions with drugs and food.2

The high rate of drug poisoning in Brazil is characterized by several factors, among them the wide variety of formulations present in the retail market that may present doubtful safety and efficacy, the proliferation of pharmacies and drugstores that facilitate indiscriminate access to the drug, errors. prescription and pharmaceutical dispensation, the increase of advertising by the pharmaceutical industry, allied to a weakness in preventive measures and the ability to supervise and control by the authorities, as well as the practice of selfmedication, leading to the irrational use of medicines. 3

The aim of this paper is to evaluate the occurrence of drug poisoning in children, identifying the main classes and factors involved according to a literature review.

\section{METHODOLOGY}

This was a descriptive study, of the bibliographic review type, conducted in August 2019. The descriptors "intoxication", "medicines" and "children" were searched, integrated in the database of the Virtual Health Library for SCIELO and MEDLINE databases were contemplated. These descriptors were crossed in different ways to fit the researchers' desire and fit the theme of the review. Among the inclusion criteria were the Portuguese language, research from the last ten years that addressed the topic of drug intoxication in children. Articles that addressed the theme of drug toxicity in adults and that were outside the research context were excluded. After initial reading of the title and abstract, articles were selected for full reading and discussion. Then 6 (six) articles that were in agreement with the proposal of this work were selected.

\section{RESULTS}

According to data from the National ToxicPharmacological Information System (SINITOX), in general, drug intoxication was the main type of intoxication in 2017, accounting for $25.18 \%$ of all notified cases. Of this portion, 2,281 cases of drug intoxication were reported in children aged 0 to 9 years, representing $33 \%$ of the total cases of this type of intoxication. ${ }^{4}$ This fact can be justified by three factors: inherent to their own childhood (such as their own). pharmacodynamic and pharmacokinetic differences: curiosity during the development phase, lack of danger and poorly developed taste); the lack of a drug development policy specific to this group; lack of information from the guardians about the medications, especially regarding self-medication, improper storage and lack of guidance regarding the use and risks offered. ${ }^{5}$ The main medications involved were nasal decongestants, bronchodilators, analgesics and anti- inflammatories, anticonvulsants and contraceptives. oral. The main form of poisoning was by oral ingestion. ${ }^{6}$

Drug poisoning is a common childhood accident. Colored packaging and liquids, candy-shaped tablets, improper storage are some of the factors that lead children to take large doses of medicines. On the other hand, the growth of information via the internet, lead some parents to medicate their children unrestrictedly. Unnecessary and incorrect drug use and the risk of adverse events and intoxications to which children are exposed do not reflect rational use of these drugs ${ }^{7}$

The circumstances of drug poisoning vary by age group. In younger children (up to 6 months of age), most cases involve the 
administration of medication or other substances by their guardians. With psychomotor development, the child becomes more independent, exposing himself to greater risks, going through the "mouth to mouth" phase to a more selective phase in which they ingest what has the most attractive color and taste. ${ }^{8}$ Children to become more skilled open most containers and packaging. Teenagers can become intoxicated by practicing self-medication, attempting suicide and even during work activities, in case of pesticides and pesticides. ${ }^{9}$

Although the main cause of this type of intoxication is suicide attempt in the child population, the main causes reported in the reported articles were due to accidents, or even after a medical prescription, with errors in administration. It is also worth mentioning the report of cases of poisoning due to selfmedication of children by parents and / or guardians. A study by Maior and Oliveira revealed that incidents with children aged 0 to 1 year were related to nasal decongestants and bronchodilators, due to the high incidence of respiratory diseases in this period of childhood. 10 Within this same range, analgesics, antipyretics and Anti-inflammatory drugs also matter. In the 2- to 4-year group, in addition to the previously mentioned medications, the use of psychotropic drugs was also relevant, since small doses can lead to symptoms such as drowsiness, cerebellar ataxia and respiratory failure. The use of antimicrobials and antiparasitic agents are also related to toxic events, but in smaller quantities than the classes mentioned above. Of this class, amoxicillin and benzyl benzoate are the main drugs involved in cases of poisoning in the age group of 1 to 4 years.

Most cases of drug poisoning occur in the home environment due to the existence of so-called "home pharmacies" that consequently increase the risk of accidental ingestion of drugs mainly by children, also occurring improper storage of drugs, because they are expired and / or use on their own. without the guidance of the appropriate professional. ${ }^{11}$

\section{CONCLUSION}

The occurrence of drug intoxications is frequently registered in health systems, and the percentages are higher in children. The use of medicines stored at home from leftovers from previous treatments in children is one of the reasons that aggravate the issue. Thus, it is of fundamental importance that the teaching about the use of medicines is carried out from the first years of life, showing the importance and the danger that medicines can cause, thus highlighting the importance of poisoning prevention actions.

The professional pharmacist within his / her qualifications is a professional trained to provide assistance, whose main objective is to guide and raise awareness, working on the review of prescribing practices in children, as well as health policies related to the use of medicines, combating the self-medication culture, aiming, finally, to reduce cases of childhood drug intoxication.

\section{REFERENCES}

1. Anvisa. Agência Nacional de Vigilância Sanitária. Regras Básicas de Propaganda. [livro online] Brasília: 2016. [acesso em 19 ago 2019] Disponível em: portal.anvisa.gov.br/regrasbasicas-de-propaganda.

2. Nóbrega $\mathrm{H}$ et. al. Intoxicações por Medicamentos: Uma Revisão Sistemática com Abordagem nas Síndromes Tóxicas. Rev. Saúde e Ciênc. 2015: 4(2):109-119.

3. Klinger $E$ et al. Intoxicação exógena por medicamentos na população jovem do Rio Grande do Sul. Rev. epidemiol. controle infecç. 2016:1(1):282-286.

4. Sinitox. Sistema Nacional de Informações TóxicoFarmacológicas. Casos Registrados de Intoxicação Humana por Agente Tóxico e Faixa Etária. [livro online] Rio de janeiro: 2017. [acesso em 30 ago 2019] Disponível em sinitox.icict.fiocruz.br/sites/sinitox.icict.fiocruz.br/fi les//Brasil7.pdf.

5. Maior $M$ et al. Internações por intoxicações medicamentosas em crianças menores de cinco anos no Brasil, 2003-2012*. Epidemiol. Serv. Saúde. 2017:26(4):771-782.

6. Witter $A$ et al. Intoxicação medicamentosa em crianças: Uma revisão de literatura. Revinter, 
[revista em Internet] 2016 [acesso 25 de agosto

de 2019]; 9(3) Disponível em:

http://www.revistarevinter.com.br/minhas-

revistas/2016/v-9-n-3-2016-volume-9-numero-3-

out-de-2016-sao-paulo/35-intoxicacao-

medicamentosa-em- criancas-uma-revisao-deliteratura/file.

7. Silva T, Oliveira V. Intoxicação Medicamentosa Infantil no Paraná. Visão Acad. 2018:19(1):51-61.

8. Feuser P. Perfil das intoxicações medicamentosas no Estado de Santa Catarina. Rev. Saúde Públ. 2013;6(2):23-32.

9. Maior M, Oliveira N. Intoxicação medicamentosa infantil: um estudo das causas e ações preventivas possíveis. Rev. Bras. Farm. 2012:4(93):422-430.

10. Paiva $A$ et al. IMPACTO DOS MEDICAMENTOS NAS INTOXICAÇÕES EM CRIANÇAS. Rev. Ibirap. 2017:1(13):8-16.

11. Saraiva $E$ et al. Panoramas das Intoxicações por Medicamentos no Brasil. Revista E-ciência [revista em Internet] 2017 [acesso 19 de agosto de 2019]; 5(2). Disponível em: https://www.fjn.edu.br/pesquise/wpcontent/uploads/2018/04/Panorama-dasIntoxica\%C3\%A7\%C3\%B5es.pd f. 